\title{
Graphite-sulfide deposits in Ronda and Beni Bousera peridotites (Spain and Morocco) and the origin of carbon in mantle-derived rocks
}

\author{
E. Crespo ${ }^{\text {a }}$, F.J. Luque ${ }^{\text {a,* }}$, M. Rodas ${ }^{\text {a }}$, H. Wada ${ }^{b}$, F. Gervilla ${ }^{c}$ \\ a Dpto. Cristalografía y Mineralogía, Facultad de Geología, Universidad Complutense, 28040 Madrid, Spain \\ ${ }^{\mathrm{b}}$ Department of Biology and Geosciences, Shizuoka University Ohya 836-1, Shizuoka 422-8529, Japan \\ c Dpto. Mineralogía y Petrología, Facultad de Ciencias, Universidad de Granada, 18002 Granada, Spain
}

\begin{abstract}
This paper describes unusual graphite-sulfide deposits in ultramafic rocks from the Serranía de Ronda (Spain) and Beni Bousera (Morocco). These deposits occur as veins, stockworks and irregular masses, ranging in size from some centimeters to a few meters in thickness. The primary mineral assemblage mainly consists of $\mathrm{Fe}-\mathrm{Ni}-\mathrm{Cu}$ sulfides (pyrrhotite, pentlandite, chalcopyrite and cubanite), graphite and chromite. Weathering occurs in some sulfide-poor deposits that consist of graphite (up to 90\%), chromite and goethite. Texturally, graphite may occur as flakes or clusters of flakes and as rounded, nodule-like aggregates. Graphite is highly crystalline and shows light carbon isotopic signatures $\left(\delta^{13} \mathrm{C} \approx-15 \%\right.$ to $-21 \%$ ). Occasionally, some nodule-like graphite aggregates display large isotopic zoning with heavier cubic forms (probably graphite pseudomorphs after diamond with $\delta^{13} \mathrm{C}$ up to $-3.3 \%$ ) coated by progressively lighter flakes outwards $\left(\delta^{13} \mathrm{C}\right.$ up to $\left.-15.2 \%\right)$.

Asthenospheric-derived melts originated the partial melting (and melt-rock reactions) of peridotites and pyroxenites generating residual melts from which the graphite-sulfide deposits were formed. These residual melts concentrated volatile components $\left(\right.$ mainly $\mathrm{CO}_{2}$ and $\left.\mathrm{H}_{2} \mathrm{O}\right)$, as well as $\mathrm{S}$, As, and chalcophile elements. Carbon was incorporated into the melts from the melt-rock reactions of graphite-bearing (formerly diamonds) garnet pyroxenites with infiltrated asthenospheric melts. Graphite-rich garnet pyroxenites formed through the UHP transformation of subducted kerogen-rich crustal material into the mantle. Thus, graphite in most of the studied occurrences has light (biogenic) carbon signatures. Locally, reaction of the light carbon in the melts with relicts of ${ }^{13} \mathrm{C}$-enriched graphitized diamonds (probably generated from hydrothermal calcite veins in the subducting oceanic crust) reacted with the partial melts to form isotopically zoned nodule-like graphite aggregates.
\end{abstract}

Keywords: Graphite; Carbon isotopes; Ultramafic rocks; Ronda; Beni Bousera

\section{Introduction}

Native carbon in mantle-derived rocks occurs both as diamond and graphite. Most diamond occurrences are restricted to specific rock types, mainly kimberlites, in cratonic areas. However, graphite has been reported in a wide variety of mantle-derived rocks in different geologic environments: basalts (Pineau et al., 1987; Barrenechea et al., 1997), andesites (Strens, 1965), peridotites (Luque et al., 1992), mantle xenoliths (Mathez, 1987; Deines, 2002), and mafic rocks in layered intrusions (Hollister, 1980; Ballhaus and Stumpfl,

\footnotetext{
* Corresponding author.

E-mail address: jluque@geo.ucm.es (F.J. Luque).
}

1985; Ripley and Taib, 1989). The origin of carbon in mantlederived rocks is controversial. In some cases, particularly for peridotite-type diamonds, carbon is thought to be indigenous to the mantle. In other cases, e.g. eclogitic-type diamonds, it is assumed that carbon has been incorporated into the mantle via subduction of crustal rocks (Milledge et al., 1983; Gurney, 1990; Pearson and Nixon, 1996). Finally, for some graphite occurrences carbon is considered to have been assimilated from carbonaceous country rocks during magma ascent or emplacement (Ripley and Taib, 1989; Barrenechea et al., 1997; Luque et al., 1998).

In any case, carbon isotopes are powerful tools to unravel the origin of carbon in mantle-derived rocks. Typical mantle $\delta^{13} \mathrm{C}$ values are considered to be about $-5 \%$, which corresponds to carbon found in MORB, OIB, carbonatites, 
carbonate from kimberlites and peridotitic diamonds (Deines, 2002). Large departures from such values in mantle-derived diamond (framesites and eclogite diamonds) or graphite have been interpreted as mixed carbon sources (mostly with subducted biogenic carbon) or as the result of kinetic fractionation processes (Mattey, 1987; Pineau et al., 1987; Kirkley et al., 1991; Schulze et al., 1997; Cartigny et al., 1998; Maruoka et al., 2004).

This paper deals with an unusual type of magmatic graphite-sulfide mineralization in ultramafic rocks from Spain and Morocco, describing the geologic and mineralogical features of the deposits. The origin of carbon and the way in which it was concentrated are discussed on the basis of these characteristics and carbon isotope data.

\section{Geologic setting}

The ultramafic rocks of the Serranía de Ronda (southern Spain) and Beni Bousera massif (northern Morocco) are located in the Betic-Rifean orogenic belt, which is the westernmost part of the Mediterranean Alpine belt. The ultramafic rocks of the Serranía de Ronda crop out in three separated massifs: the Ronda massif (considered to be the world's largest exposure of orogenic lherzolites), the Ojén massif, and the Carratraca massif. The massifs are overlain by metamorphic rocks that display decreasing metamorphic grade outwards from the contact with the peridotite rocks and thrust over variably graded metamorphic rocks (Fig. 1).

The ultramafic massifs of southern Spain and northern Morocco are made up of lherzolites and harzburgites with minor dunites, different types of pyroxenite layers, and leucocratic dikes. The pyroxenite layers are generally parallel to the foliation of the peridotites and the leucocratic dikes always cross-cut such foliation. Geochemical and isotope studies in the pyroxenite layers point to crustal recycling (Kornprobst et al., 1990; Pearson et al., 1991a; Pearson et al., 1993; Blichert-Toft et al., 1999; Morishita et al., 2003; Pearson and Nowell, 2004). This clearly establishes that subduction played an important role in the petrogenesis of the massifs. The leucocratic dikes of granitic composition were generated by partial melting of the underlying migmatites during the emplacement of the ultramafic rocks into the crust (Sánchez-Rodríguez and Gebauer, 2000; Pereira et al., 2003).

The ultramafic massifs are considered to be portions of an old (Proterozoic) subcontinental lithospheric mantle emplaced tectonically in the lower crust $22 \mathrm{Myr}$ ago. Before their emplacement they suffered partial melting and infiltration of asthenospheric melts resulting in the development of a recrystallization front (Van der Wal and Bodinier, 1996; Garrido and Bodinier, 1999; Lenoir et al., 2001). A distinctive

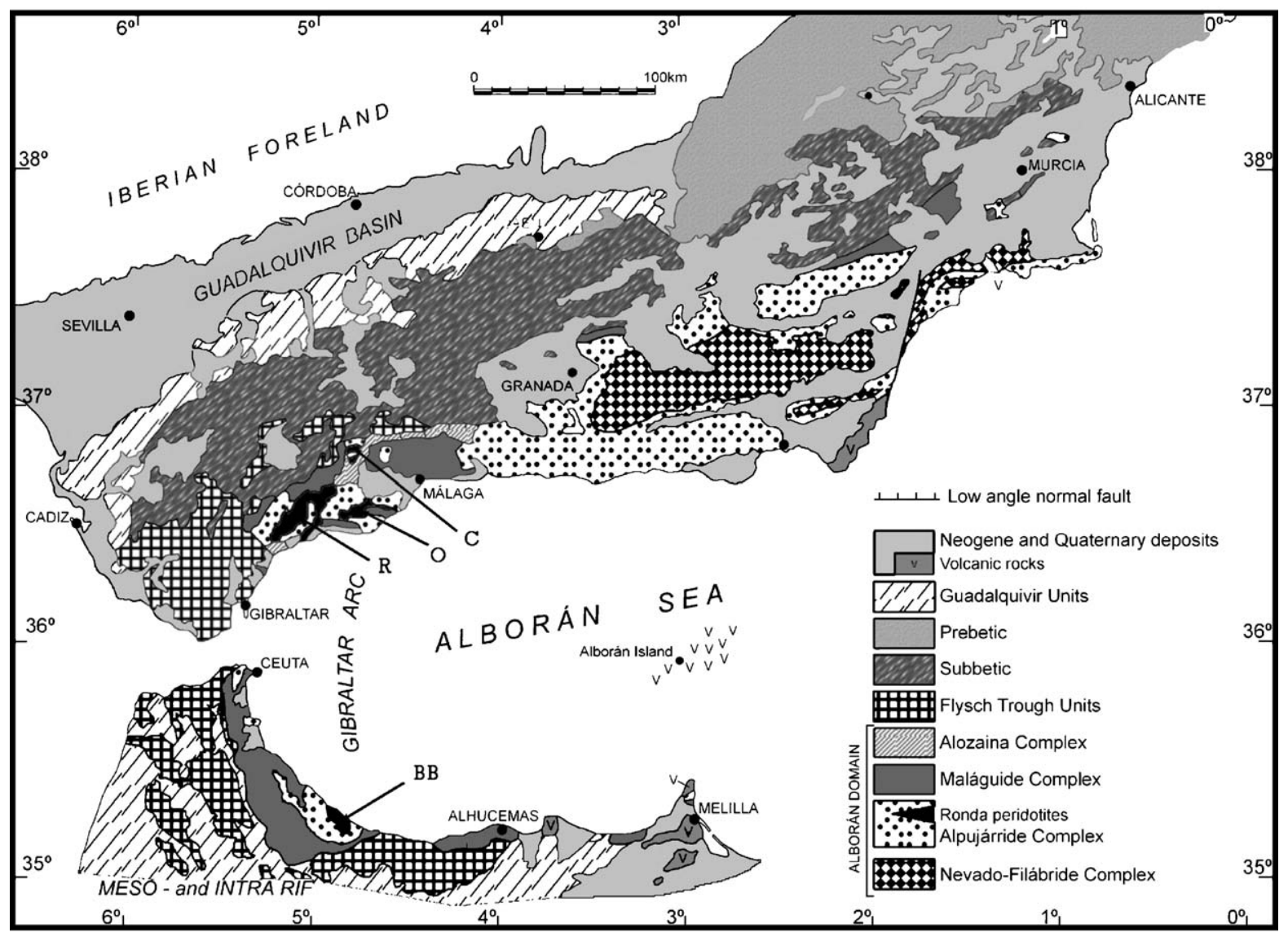

Fig. 1. Geological map of the Alpine belt in southern Spain and Morocco showing the location of the peridotite massifs (after Sánchez-Gómez et al., 2002). R: Ronda, O: Ojén, C: Carratraca, BB: Beni Bousera. 

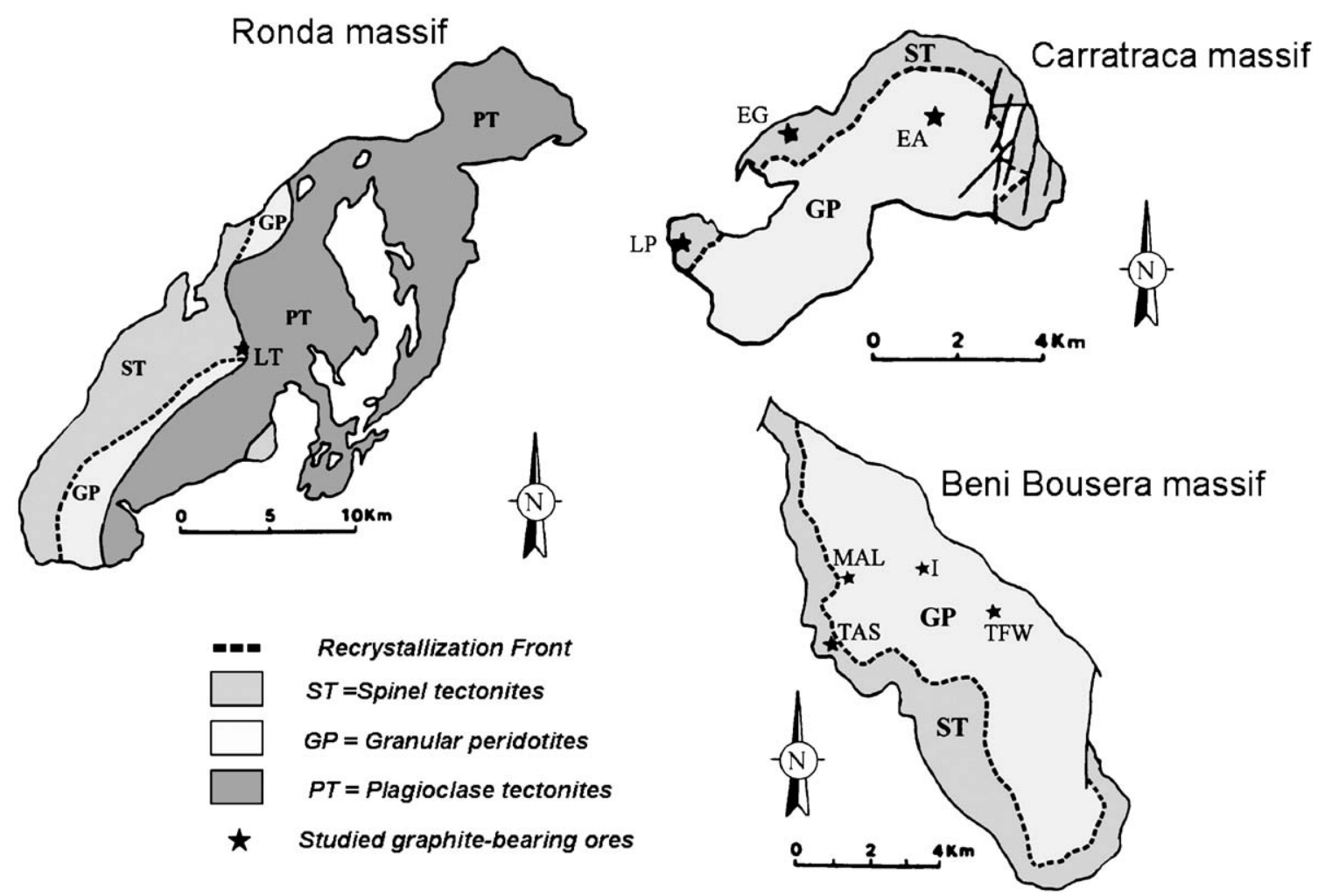

Fig. 2. Geological sketch of the ultramafic massifs of Ronda, Carratraca and Beni Bousera and location of the studied deposits. LT: Mina Marbella, LP: Los Pobres, EA: El Águila, EG: El Gallego, MAL: Malijan, TAS: Tasitan, TFW: Tafart West, I: Mina del Río.

feature of all these massifs is a petrological zoning into three domains (Fig. 2):

a) The spinel tectonite domain, located above the recrystallization front and representing the rest of the ancient protolith, is composed of spinel and garnet-spinel peridotites. Graphite pseudomorphs after diamond have been found in some garnet pyroxenite layers of this domain (Slodkevich, 1983; Pearson et al., 1991b, 1995; Davies et al., 1993; Pearson and Nixon, 1996). These graphitized diamonds may represent up to $15 \%$ in volume of the rock and reach up to $20 \mathrm{~mm}$ in size (Slodkevich, 1983; Pearson et al., 1989; Davies et al., 1993).

b) The granular peridotite domain, located immediately below the recrystallization front, includes spinel peridotites formed by re-equilibration of the preexisting spinel tectonites with the partial melts and infiltrated melts.

c) The plagioclase tectonite domain, composed of plagioclase peridotites, is the youngest one, and was developed from granular peridotites during the crustal emplacement of the massif.

Related to this petrological zoning, three types of magmatic ores have been recognized (Gervilla and Leblanc, 1990; Gervilla et al., 2002):

1) Chromium-nickel $(\mathrm{Cr}-\mathrm{Ni})$ ores. They occur as veins or layers (discordant to the foliation of the host peridotite) and consist of chromite with intergranular nickel arsenides (mainly niccolite). Some of the ore bodies contain traces of graphite. This type of ore is generally found above the recrystallization front, that is, in the spinel tectonite domain.

2) Sulfide-graphite $(S-G)$ ores. They are found as veins, stockworks and irregular masses with very variable size (from a few centimeters to a few meters in thickness). Their primary mineral assemblage mainly consists of $\mathrm{Fe}-\mathrm{Ni}-\mathrm{Cu}$ sulfides, chromite and graphite. These ores are associated with late fault zones within the spinel-tectonite domain (above the recrystallization front) or very close to the front, in the granular domain.

3) Chromium (Cr) ores. They consist of massive chromite and do not contain graphite at all. This type of ore occurs within the plagioclase tectonite domain.

In spite of the vein-shaped morphology of some of these deposits (mainly the $\mathrm{S}-\mathrm{G}$ ores), derivation from hydrothermal fluids can be ruled out on the basis of textural evidence, compositional trend of chromite in the different ores, association with specific petrological domains of each type of mineralization, and lack of hydrothermal alteration in the wall rocks (Gervilla and Leblanc, 1990).

This study is focused on the characteristics of the $\mathrm{S}-\mathrm{G}$ ores. In addition, we also present carbon isotope data of graphite from some $\mathrm{Cr}-\mathrm{Ni}$ ores, to trace the behaviour of carbon during the evolution of the magmatic mineralization processes. A detailed description of the mineralogy, textures, and mineral composition of these magmatic deposits can be found in the papers by Gervilla and Leblanc (1990) and Gervilla et al. 
(2002). The characterization of graphite from two $\mathrm{S}-\mathrm{G}$ deposits from southern Spain has been previously reported by Luque et al. (1992).

\section{Analytical methods}

The structural characterization of graphite was carried out by means of X-ray diffraction (XRD) and Raman spectroscopy on concentrates obtained by acid treatment as described by Luque et al. (1993). The XRD study was performed with a Siemens Kristalloflex 810 diffractometer, using $\mathrm{Cu}-\mathrm{K} \alpha$ radiation at $30 \mathrm{kV}$ and $40 \mathrm{~mA}$, a step size of $0.03\left({ }^{\circ} 2 \theta\right)$, and time per step of $1 \mathrm{~s}$. Each sample was run at least twice using silicon as internal standard. The Raman spectroscopy study was carried out with a DILOR XY Raman Spectrometer attached to an Olympus metallographic microscope. The excitation was done using an $\mathrm{Ar}^{+}$laser beam focused through the microscope objective. The measurements were done under the usual experimental conditions $(\lambda=514.5 \mathrm{~nm}, 100 \times$ objective, $\mathrm{NA}=0.95$ ), so the nominal spatial resolution was around $1 \mu \mathrm{m}$. The position, height, width (FWHM), and area of the disorder peak $\left(D\right.$, at $\left.\approx 1360 \mathrm{~cm}^{-1}\right)$ and order peak $(O$, at $\left.\approx 1582 \mathrm{~cm}^{-1}\right)$ were measured. The $(D / D+O) \times 100$ area ratio is inversely correlated with the in-plane crystallite size $\left(L_{\mathrm{a}}\right)$ which has been calculated from the estimations of Wopenka and Pasteris (1993). The second order Raman spectra were recorded from 2500 to $3100 \mathrm{~cm}^{-1}$.

Thermal properties and carbon content of graphite were determined by simultaneous recording of differential thermal analysis (DTA) and thermogravimetric (TG) curves. Samples were heated at $10{ }^{\circ} \mathrm{C} / \mathrm{min}$ in the range 20 to $1000{ }^{\circ} \mathrm{C}$ with a continuous air supply of $50 \mathrm{~mL} / \mathrm{min}$ in a Seiko TG/DTA $320 \mathrm{U}$ apparatus. Alumina was used as reference material.

Selected graphite samples were studied by scanning electron microscopy (SEM) with a Jeol JSM6400 microscope operated at $40 \mathrm{kV}$. These samples were previously acid-treated (HF) to remove superficial oxi-hydroxides.

The bulk stable carbon isotope ratio of single graphite grains and nodule-like aggregates was measured at the Department of Geoscience, Shizuoka University (Japan). To look for isotopic zoning, both largest individual graphite crystals and nodule-like aggregates were microsampled. Single graphite flakes were exfoliated perpendicular to the $c$-axis using the method described by Wada (1988) and Arita and Wada (1990). Small volumes of graphite $(10-15 \mu \mathrm{g})$ were obtained from different parts of nodule-like aggregates using a surgical needle. Equipment and sample preparation for the isotopic analysis are described in Satish-Kumar et al. (2002) and references therein. The precision of these analyses is $\pm 0.05 \%$.

Nodule-like graphite aggregates were also analysed by ion microprobe (Secondary Ion Mass Spectrometry, SIMS) to look for microscale isotopic zoning. Carbon isotope microanalyses of graphite were performed at CRPG-CNRS (Nancy, France) using a CAMECA ims-1270 ion microprobe. Goldcoated graphite polished section samples were sputtered with a $14 \mathrm{keV} \mathrm{Cs}^{+}$primary beam defocused to a $\sim 25-30 \mu \mathrm{m}$ diameter spot. Precision of the analyses is better than $\pm 1 \%$. Instrumental mass fractionation was corrected using natural graphite standards of this laboratory calibrated by conventional mass spectrometry.

\section{Sulfide-graphite ores}

Sulfide-graphite ores are found as veins, stockworks and irregular masses with very variable size (from some centimeters to few meters in thickness). Lateral extension is up to some tens of meters. Some of these deposits were exploited in the past. In some occurrences (those sulfidepoor) weathering has transformed the original sulfides into earthy masses of $\mathrm{Fe}$ oxi-hydroxides containing irregular to rounded graphite concentrations (Fig. 3a, b). In the unaltered ores, the primary mineral assemblage mainly consists of $\mathrm{Fe}-$ $\mathrm{Ni}-\mathrm{Cu}$ sulfides (pyrrhotite, pentlandite, chalcopyrite and cubanite), graphite and chromite (Fig. 3c). Graphite content varies from $10 \%$ to $60 \%$ in volume. Accessory phases include rutile, bravoite, magnetite, maucherite, mackinawite and cobaltite (Gervilla and Leblanc, 1990). Weathered S-G ores contain up to 90 vol.\% graphite, chromite and $\mathrm{Fe}$ oxihydroxides (mainly goethite), with trace amounts of the original sulfides. Gangue minerals in both types of occurrences may include olivine, pyroxenes, plagioclase and phlogopite.

Texturally, graphite in the $\mathrm{S}-\mathrm{G}$ ores may occur as flakes or clusters of flakes (Fig. 3d, e) and as rounded, nodule-like aggregates. Graphite flakes may reach up to $0.5 \mathrm{~mm}$ long. Nodule-like aggregates, up to 7-8 $\mathrm{mm}$ in diameter, are composed of thicker graphite crystals in the core with a rim of thin flakes (Fig. 3f).

\section{Graphite characterization}

Structural and thermal characteristics of graphite from the studied occurrences are given in Table 1. The structural characterization of graphite by XRD shows that the basal spacing $d_{002}$ is close to $3.35 \AA$. Diffraction peaks of rhombohedral graphite were not recorded in the diffraction patterns. The continuity of graphite layers along the stacking direction ( $c$-axis) is large as revealed by the values of crystallite size $L_{\mathrm{c}}(>420 \AA)$. The graphitizing degree (G.D. $\left.=130-500\right)$ is in the range given for fully ordered, high-temperature metamorphic graphite. Thus, for the different occurrences studied both in Spain and Beni Bousera all the measured parameters correspond to those of hexagonal graphite with a high degree of structural order along the stacking direction. Considering the values of the $c$ parameter $\left(c=d_{002} \times 2\right)$ and using the geothermometric estimation of Shengelia et al. (1979) the minimum temperature of formation of graphite is in the range between 660 and $840{ }^{\circ} \mathrm{C}$. In addition, the thermal characteristics are also typical of highly crystalline graphite with a strong exothermic maximum in the range $800-750{ }^{\circ} \mathrm{C}$ (Table 1).

First order Raman spectra of graphite from $\mathrm{S}-\mathrm{G}$ ores show a sharp peak of order at $\approx 1580 \mathrm{~cm}^{-1}$, and a weak or absent 

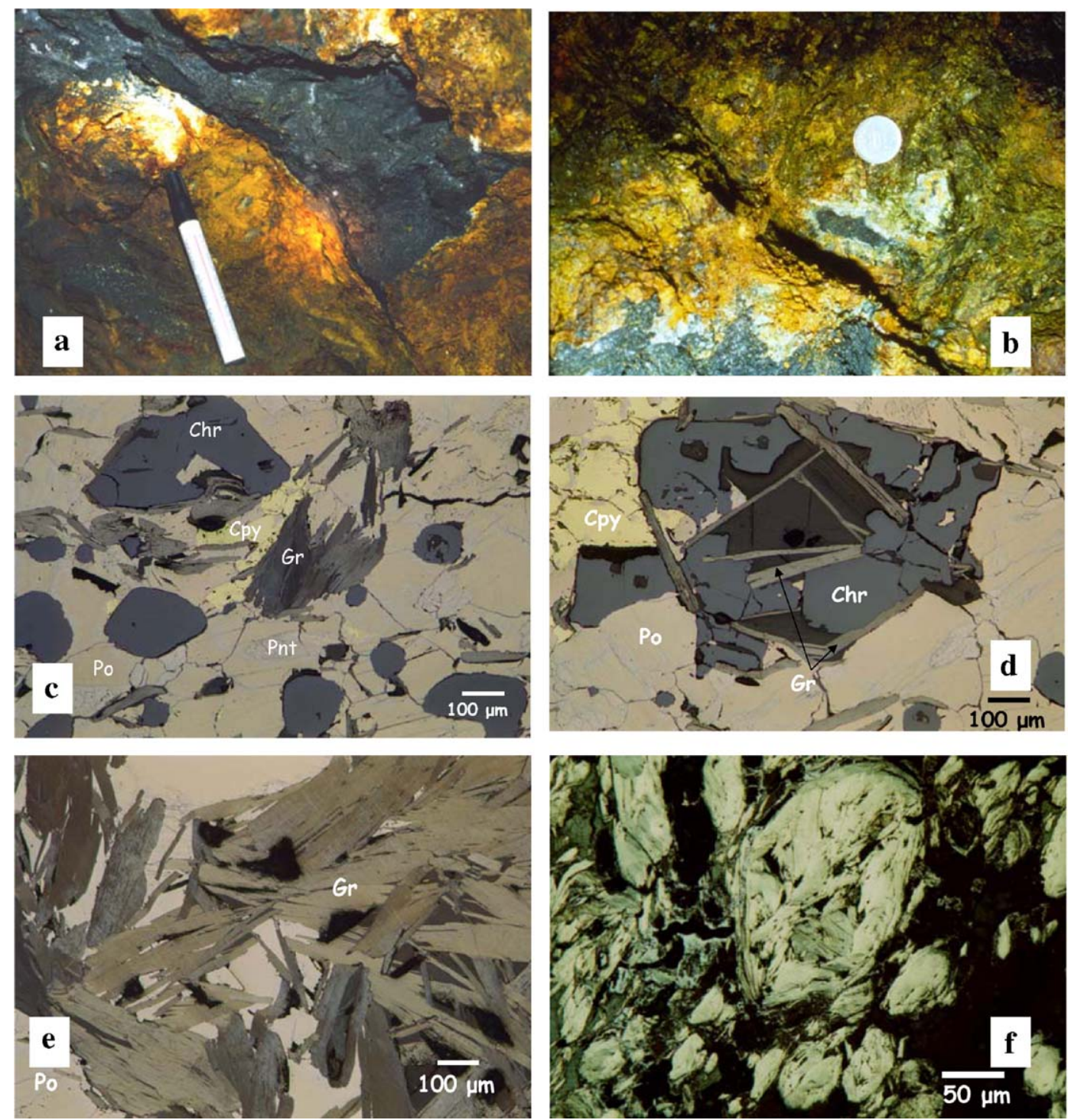

Fig. 3. a) Irregularly shaped graphite-rich concentration filling a fracture in serpentinized peridotite. Note the presence of yellowish earthy masses of iron oxihydroxides due to weathering of primary sulfides (Los Pobres mine). Pen for scale is $135 \mathrm{~mm}$ long; b) Detail of rounded graphite concentrations in the groundmass of "limonite". Coin for scale is $25 \mathrm{~mm}$ in diameter; c) Reflected light microphotograph showing the primary mineral assemblage of a S-G ore (sample I-6 from Mina del Río occurrence); d) Isolated graphite flakes within chromite (sample I-6 from Mina del Río occurrence); e) Cluster of graphite crystals (sample I-4 from Mina del Río occurrence); f) Nodule-like graphite aggregate (sample LT-20 from Mina Marbella occurrence). Gr: graphite; Chr: chromite; Pnt: pentlandite; Po: pyrrhotite; Cpy: chalcopyrite.

disorder band at $\approx 1350 \mathrm{~cm}^{-1}$ (Fig. 4a). The intensity and area ratios for these two bands are very low. The second order spectra show a well-defined shoulder at $\approx 2685 \mathrm{~cm}^{-1}$ on the S-peak (Fig. 4b). All these features are indicative of a high degree of crystalline perfection along the basal plane, with crystallite size $L_{\mathrm{a}}$ in excess of $500 \AA$ according to the estimation of Wopenka and Pasteris (1993). Such features are similar to those reported for graphite formed at high temperature in mantle-derived xenoliths (Pearson et al., 1994), and also to those of graphite pseudomorphs after diamond in Beni Bousera pyroxenites (Pearson and Nixon, 1996).

Stable carbon isotope analyses show that graphite in the $\mathrm{Cr}-\mathrm{Ni}$ ores is lighter than that in the $\mathrm{S}-\mathrm{G}$ ores (Fig. 5 and Table 2). The carbon isotope data from the $S-G$ ores are remarkably consistent at each locality, with the exception of the nodule data from Ronda. Flaky crystals show light isotopic signatures $\left(\delta^{13} \mathrm{C}=-14.1 \%\right.$ to $-21.6 \%$ ) usually with differences less than $1 \%$ within single crystals from a given occurrence (Table 2 and Fig. $6 \mathrm{a}$ ). The $\delta^{13} \mathrm{C}$ values from exfoliation flakes of large single crystals reveal that there is not isotopic zoning along the $c$-axis. In addition, graphite in the deposits located in the Carratraca massif is isotopically lighter than that in the other massifs. It also must be noted that there is no systematic difference in carbon isotopes between graphite in occurrences associated with granular peridotite and spinel tectonite. At Carratraca, graphite in the occurrences located in the granular peridotite domain is $1 \%$ lighter than that in spinel tectonites. At Beni Bousera, graphite in the occurrences from granular perido- 
Table 1

XRD, Raman and thermal data of graphite from the studied $\mathrm{S}-\mathrm{G}$ occurrences

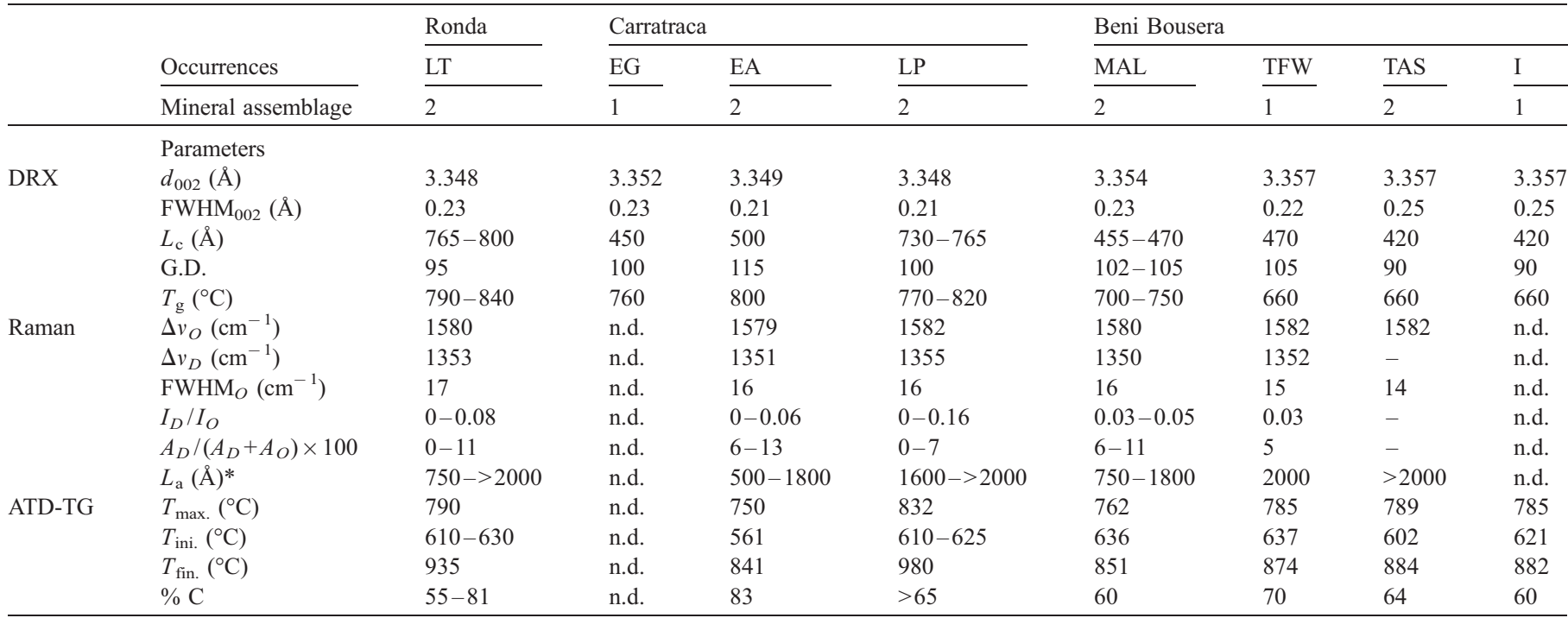

Mineral assemblages: $1=$ unaltered ores (major minerals: chromite + pentlandite + pyrrhotite + graphite \pm chalcopyrite \pm cubanite); $2=$ weathered ores $($ major minerals: chromite + graphite + goethite). Parameters: $d_{002}=002$ spacing; $\mathrm{FWHM}_{002}=$ full-width half-maximum of 002 peak; $L_{\mathrm{c}}=$ crystallite size along $c$-axis; G.D. $=$ Graphitizing degree (after Tagiri, 1981) $=\left[\left(d_{002}-3.7\right) /\left(\log L_{\mathrm{c}} / 1000\right)\right] \times 100 ; T_{\mathrm{g}}=$ temperature of formation estimated from the $c$ parameter $($ calculated after Shengelia et al., 1979); $\Delta v_{O}=$ frequency of the $O$-peak; $\Delta v_{D}=$ frequency of the $D$-peak; $\mathrm{FWHM}_{O}=$ full-width half-maximum of $O$-peak; $I_{D} / I_{O}$ $=$ disorder - order peak intensity ratio; $A_{D} /\left(A_{D}+A_{O}\right) \times 100=$ disorder - order peak area ratio; $L_{\mathrm{a}}=$ crystallite size along the basal plane (calculated after Wopenka and Pasteris, 1993); $T_{\max }=$ temperature of the exothermic maximum; $T_{\mathrm{ini}}=$ temperature of the beginning of combustion; $T_{\text {fin }}=$ final temperature of combustion; n.d. $=$ not determined.

tites is as much as $1 \%$ o heavier than that in spinel tectonites. Except for a sample from Mina del Rio, there are not significant differences in the isotopic signature of graphite flakes and aggregates from the Beni Bousera occurrences. In contrast, in samples from Mina Marbella (Ronda massif), nodule-like graphite aggregates show a large isotopic zoning ( $\delta{ }^{13} \mathrm{C}$ ranges from $-3.3 \%$ to $-15.2 \%$ ), being isotopically lighter outwards from a given crystal inside the aggregate (Fig. 6b, c).

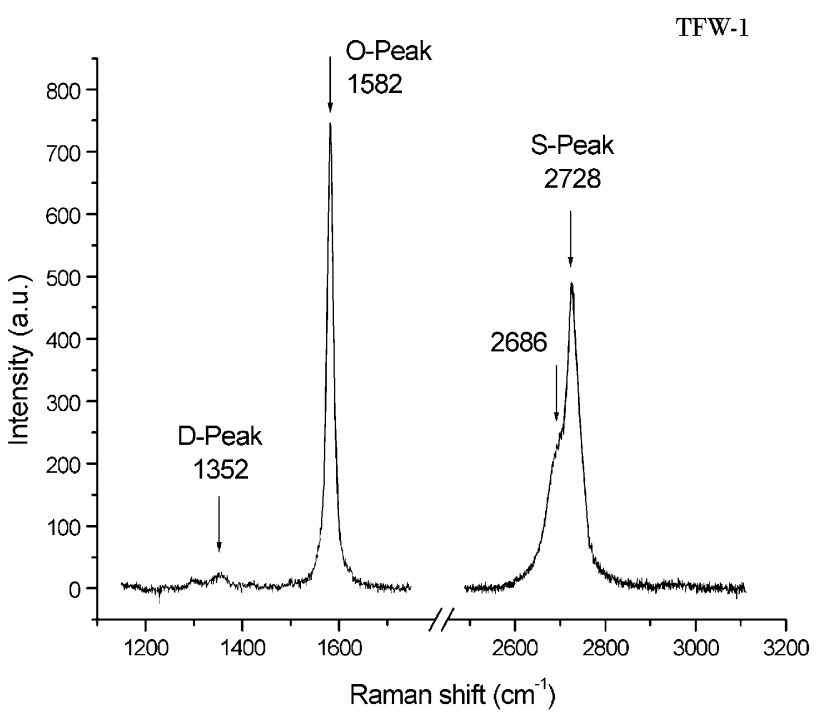

Fig. 4. First and second order Raman spectra of graphite in sample TFW-1. Note the weak D-peak in the first-order spectrum and the shoulder on the Speak in the second-order spectrum which are characteristic of highly crystalline graphite.
A SEM study carried out to search for the causes of the isotopic zoning showed that inside the aggregates there are cubic forms (composed of carbon) coated by laminar graphite crystals (Fig. 7). Therefore, we have interpreted these forms as graphitized diamonds. Similar cube-shaped graphite, also interpreted as pseudomorphic after diamond, has been de-

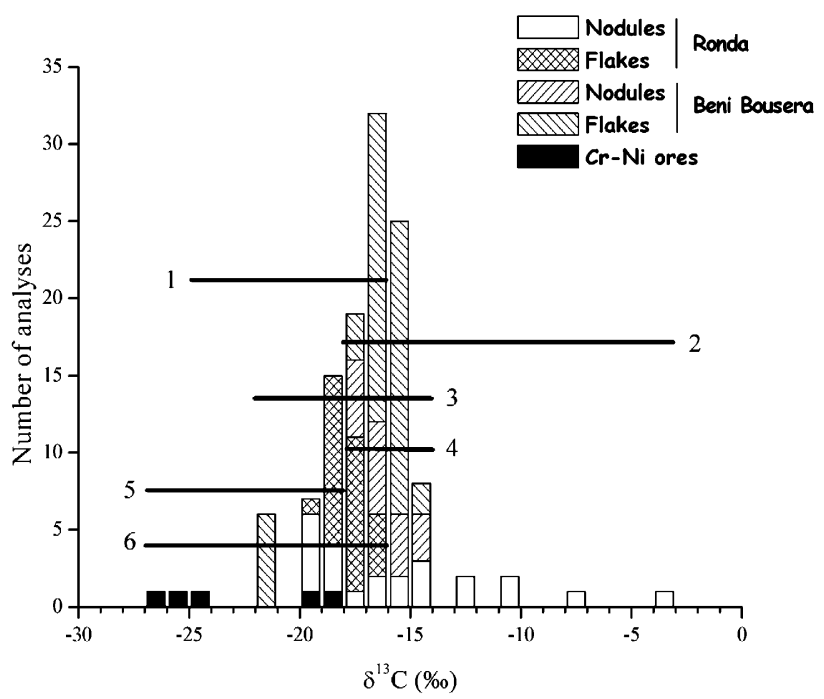

Fig. 5. Histogram showing the distribution of carbon isotope signatures in graphite from the studied occurrences. Horizontal bars show the isotopic range of the different types of graphite from the ultramafic rocks of Ronda and Beni Bousera: 1 = Graphite flakes $(\mathrm{S}-\mathrm{G}$ ores, Ronda); 2 = Graphite nodules $(\mathrm{S}-\mathrm{G}$ ores, Ronda); 3 = Graphite flakes ( $\mathrm{S}-\mathrm{G}$ ores, Beni Bousera); 4 = Graphite nodules ( $\mathrm{S}-\mathrm{G}$ ores, Beni Bousera); $5=\mathrm{Cr}-\mathrm{Ni}$ ores (Ronda and Beni Bousera); $6=$ Graphitized diamonds in garnet pyroxenites (Beni Bousera). 
Table 2

Stable carbon isotope ratios $\left(\delta^{13} \mathrm{C}\right)$ of graphite from the studied $\mathrm{S}-\mathrm{G}$ occurrences

\begin{tabular}{|c|c|c|}
\hline & Type of sample & $\delta^{13} \mathrm{C}(\%)$ \\
\hline \multicolumn{3}{|l|}{$\mathrm{Cr}-\mathrm{Ni}$ ores* } \\
\hline La Gallega & Flake & -25.8 \\
\hline San Juan & Flake & -19.9 \\
\hline San Juan & Flake & -18.0 \\
\hline San Juan & Flake & -26.1 \\
\hline Talambiden & Flake & -24.3 \\
\hline \multicolumn{3}{|l|}{$S-G$ ores } \\
\hline \multicolumn{3}{|l|}{ Ronda } \\
\hline \multicolumn{3}{|c|}{ Mina Marbella } \\
\hline LT-2 & Flake & -16.83 \\
\hline LT-16 & Flake & -16.86 \\
\hline LT-16.1 & Exfoliation flake & -17.14 \\
\hline LT-16.2 & Exfoliation flake & -16.97 \\
\hline LT-16.3 & Exfoliation flake & -17.07 \\
\hline LT-16.4 & Exfoliation flake & -17.14 \\
\hline LT-16.5 & exfoliation flake & -17.22 \\
\hline LT-16.6 & Exfoliation flake & -17.31 \\
\hline LT-16.7 & Exfoliation flake & -17.06 \\
\hline LT-16.8 & Exfoliation flake & -17.37 \\
\hline LT-20 & Nodule (Fig. 6c) & -16.43 \\
\hline LT-20 & Nodule (Fig. 6c) & -10.75 \\
\hline LT-20 & Nodule (Fig. 6c) & -16.39 \\
\hline LT-20 & Nodule (Fig. 6c) & -15.73 \\
\hline LT-20 & Nodule (Fig. 6c) & -17.24 \\
\hline LT-20a & Nodule (Fig. 6b) & -3.3 \\
\hline LT-20b & Nodule (Fig. 6b) & -7.1 \\
\hline LT-20c & Nodule (Fig. 6b) & -10.2 \\
\hline LT-20d & Nodule (Fig. 6b) & -14.3 \\
\hline LT-20e & Nodule (Fig. 6b) & -12.1 \\
\hline LT-20f & Nodule (Fig. 6b) & -14.5 \\
\hline LT-20g & Nodule (Fig. 6b) & -12.0 \\
\hline LT-20h & Nodule (Fig. 6b) & -14.2 \\
\hline LT-20i & Nodule (Fig. 6b) & -15.2 \\
\hline LT $-20 \mathrm{j}$ & Flake (Fig. 6a) & -18.0 \\
\hline LT-20k & Flake (Fig. 6a) & -17.6 \\
\hline LT-201 & Flake (Fig. 6a) & -18.5 \\
\hline LT-20m & Flake (Fig. 6a) & -18.3 \\
\hline LT-20n & Flake (Fig. 6a) & -17.8 \\
\hline LT-20o & Flake (Fig. 6a) & -17.5 \\
\hline LT-20p & Flake & -16.8 \\
\hline LT-20q & Flake & -18.0 \\
\hline \multicolumn{3}{|l|}{ El Aguila } \\
\hline EA-1 & Flake & -19.43 \\
\hline EA-1.1 & Nodule (rim) & -19.37 \\
\hline EA-1.2 & Nodule (rim) & -19.60 \\
\hline EA-1.3 & Nodule (core) & -19.99 \\
\hline EA-1.4 & Nodule (rim) & -19.82 \\
\hline EA-1.5 & Flake & -19.74 \\
\hline \multicolumn{3}{|l|}{ El Gallego } \\
\hline EG-2.1 & Nodule & -18.41 \\
\hline EG-2.2 & Flake & -18.64 \\
\hline EG-2.3 & Flake & -18.80 \\
\hline EG-2.4 & Flake & -18.15 \\
\hline EG-2.5 & Flake & -18.33 \\
\hline EG-7.1 & Nodule & -18.40 \\
\hline EG-7.2 & Flake & -18.61 \\
\hline EG-13.1 & Flake & -18.70 \\
\hline EG-13.2 & Flake & -18.98 \\
\hline EG-13.3 & Nodule & -18.70 \\
\hline \multicolumn{3}{|l|}{ Beni Bousera } \\
\hline \multicolumn{3}{|l|}{ Tasitan } \\
\hline TAS-1.1 & Flake & -16.49 \\
\hline
\end{tabular}

Table 2 (continued)

\begin{tabular}{|c|c|c|}
\hline & Type of sample & $\delta^{13} \mathrm{C}(\%)$ \\
\hline \multicolumn{3}{|l|}{$S-G$ ores } \\
\hline \multicolumn{3}{|l|}{ Beni Bousera } \\
\hline \multicolumn{3}{|l|}{ Tasitan } \\
\hline TAS-1.2 & Flake & -16.08 \\
\hline TAS-1.3 & Flake & -16.24 \\
\hline TAS-1.4 & Flake & -16.42 \\
\hline TAS-1.5 & Flake & -15.71 \\
\hline \multicolumn{3}{|l|}{ Malijan } \\
\hline MAL-1 & Flake & -15.92 \\
\hline MAL-1 1.1 & Flake & -16.99 \\
\hline MAL-1 1.2 & Flake & -16.55 \\
\hline MAL-1 2.1 & Flake & -16.99 \\
\hline MAL-1 2.2 & Flake & -17.15 \\
\hline MAL-1 2.3 & Flake & -17.01 \\
\hline MAL-1 3.1 & Flake & -17.77 \\
\hline MAL-1 3.2 & Flake & -16.80 \\
\hline MAL-2 & Flake & -16.28 \\
\hline MAL-2.1 & Flake & -17.08 \\
\hline MAL-2.2 & Flake & -16.49 \\
\hline MAL-2.3 & Flake & -16.13 \\
\hline MAL-2.4 & Flake & -16.22 \\
\hline MAL-2.5 & Flake & -16.55 \\
\hline MAL-2.6 & Flake & -16.18 \\
\hline MAL-2.7 & Flake & -16.05 \\
\hline MAL-2.8 & Flake & -16.30 \\
\hline MAL-2.9 & Flake & -16.11 \\
\hline MAL-2.10 & Flake & -16.32 \\
\hline MAL-2.11 & Flake & -17.28 \\
\hline MAL-2.12 & Flake & -16.96 \\
\hline MAL-3.1 & Nodule (core) & -17.12 \\
\hline MAL-3.2 & Nodule (rim) & -16.40 \\
\hline MAL-3.3 & Nodule (rim) & -16.70 \\
\hline MAL.3.4 & Nodule (rim) & -16.22 \\
\hline MAL.3.5 & Nodule (rim) & -16.36 \\
\hline \multicolumn{3}{|l|}{ Tafart West } \\
\hline TFW-1 & Flake & -15.47 \\
\hline TFW-1 & Flake & -15.95 \\
\hline TFW-1.1 & Exf. flake & -15.46 \\
\hline TFW-1.2 & Exf. flake & -15.63 \\
\hline TFW-1.3 & Exf. flake & -15.23 \\
\hline TFW-1.4 & Exf. flake & -15.20 \\
\hline TFW-1.5 & Exf. flake & -15.12 \\
\hline TFW-1.6 & Exf. flake & -15.52 \\
\hline TFW-1.7 & Exf. flake & -16.27 \\
\hline TFW-2 & Flake & -14.15 \\
\hline TFW-2 & Flake & -15.41 \\
\hline TFW-2 & Flake & -15.04 \\
\hline TFW-2 & Flake & -15.20 \\
\hline TFW-2.1 & Nodule & -15.17 \\
\hline TFW-2.2 & Nodule & -15.58 \\
\hline TFW-2.3 & Nodule & -15.59 \\
\hline TFW-2.4 & Nodule & -15.83 \\
\hline \multicolumn{3}{|l|}{ Mina del Rio } \\
\hline $\mathrm{I}-4$ & Nodule & -15.56 \\
\hline $\mathrm{I}-4$ & Nodule & -15.85 \\
\hline $\mathrm{I}-4$ & Flake & -15.19 \\
\hline $\mathrm{I}-4$ & Nodule & -17.23 \\
\hline $\mathrm{I}-4$ & Flake & -16.87 \\
\hline I-6 & Flake & -16.20 \\
\hline $\mathrm{I}-6$ & Nodule & -14.78 \\
\hline I-6 & Nodule & -15.75 \\
\hline I-6 & Flake & -17.20 \\
\hline I-6 & Flake & -15.38 \\
\hline I-6.1 & Nodule & -14.75 \\
\hline
\end{tabular}

(continued on next page) 
Table 2 (continued)

\begin{tabular}{lll}
\hline & Type of sample & $\delta^{13} \mathrm{C}(\%$ ) \\
\hline $\begin{array}{l}\text { B-G ores } \\
\text { Mina del Rio }\end{array}$ & & \\
I-6.2 & & \\
I-6.3 & Nodule & -14.76 \\
I-6.4 & Nodule & -14.48 \\
I-6 Z1 & Nodule & -15.01 \\
I-6 Z2 & Exfoliation flake & -21.38 \\
I-6 Z3 & Exfoliation flake & -21.48 \\
I-6 Z4 & Exfoliation flake & -21.62 \\
I-6 Z5 & Exfoliation flake & -21.44 \\
I-6 Z6 & Exfoliation flake & -21.54 \\
& Exfoliation flake & -21.41 \\
\hline
\end{tabular}

scribed in eclogitic gneisses from the Ural Mtns, Russia (Leech and Ernst, 1998).

\section{Discussion}

The two key points for the understanding of the studied graphite occurrences refer to the source and mechanism of concentration of carbon (that is, the large amount of carbon within the $\mathrm{S}-\mathrm{G}$ ores).

\subsection{The source of carbon}

First of all, we must consider the origin of the light carbon isotopic signatures of graphite flakes in the $\mathrm{Cr}-\mathrm{Ni}$ and $\mathrm{S}-\mathrm{G}$ ores. In addition, most of the nodule-like graphite aggregates in the $\mathrm{S}-\mathrm{G}$ ores from Beni Bousera and Ronda massifs also show light $\delta^{13} \mathrm{C}$ values (Table 2). These values are at odds with the assumed mantle origin for these deposits (Gervilla and Leblanc, 1990; Gervilla et al., 2002), since typical mantle $\delta{ }^{13} \mathrm{C}$ values are considered to be about $-5 \%$ (Deines, 2002). Secondly, we have to explain the causes for the isotopic zoning within the nodule-like aggregates from Mina Marbella.

Carbon in the parental melts of the graphite-sulfide ores is assumed to have been in the form of $\mathrm{CO}_{2}$ (Pearson et al., 1991b). At this point it is important to note that there are limits to $\mathrm{CO}_{2}$ solubility in melts. About $1.5 \% \mathrm{CO}_{2}$ is soluble in silicate melts at $1400{ }^{\circ} \mathrm{C}$ and $20 \mathrm{kbar}$ (Mattey, 1991), although higher $\mathrm{CO}_{2}$ solubilities have been reported in mantle magmas (Wyllie and Huang, 1976; Eggler et al., 1976). It also has been shown that $\mathrm{CO}_{2}$ solubility increases with increasing pressure, oxygen fugacity and magma alkalinity (Pawley et al., 1992; Lowenstern, 2001). However, there is no available data on $\mathrm{CO}_{2}$ solubility in sulfide-rich magmas as those responsible for the formation of the $\mathrm{S}-\mathrm{G}$ deposits (see next section), but such melts might contain substantial $\mathrm{CO}_{2}$.

Based on the structural data of graphite and on the temperature of the DTA exothermic peak the temperature of formation of the $\mathrm{S}-\mathrm{G}$ ores was up to ca. $800{ }^{\circ} \mathrm{C}$. The $\mathrm{CO}_{2}-$ graphite isotope fractionation at such temperature is about $5 \%$ to 7\%o (Bottinga, 1969; Chacko et al., 1991). Thus, the lightest graphite that could be formed from $\mathrm{CO}_{2}$ with a (typical) mantle source would have an isotopic signature close to $-12 \%$. However, the majority of carbon isotope data of graphite from the studied occurrences are significantly lighter than that value. Derivation of graphite in the $\mathrm{Cr}-\mathrm{Ni}$ and $\mathrm{S}-\mathrm{G}$ ores from typical mantle carbon can be therefore disregarded. This implies that a source of light carbon is needed. Deines (2002) suggests that a ${ }^{13} \mathrm{C}$-depleted carbon with an isotopic signature close to $-25 \%$ (generated through kinetic isotope effects) is also indigenous to the mantle and could explain the light carbon observed in this study, except such a source would be much less abundant than the heavier mantle carbon $(\sim-5 \%$ ).

Intermediate carbon isotope signatures can be obtained by mixing carbonaceous matter with carbonate. The relative proportions between these two sources would determine the final isotopic signature. At mantle conditions, Tappert et al. (2005) have recently reported that sublithospheric diamonds may show isotopic signatures close to $-20 \%$ derived directly
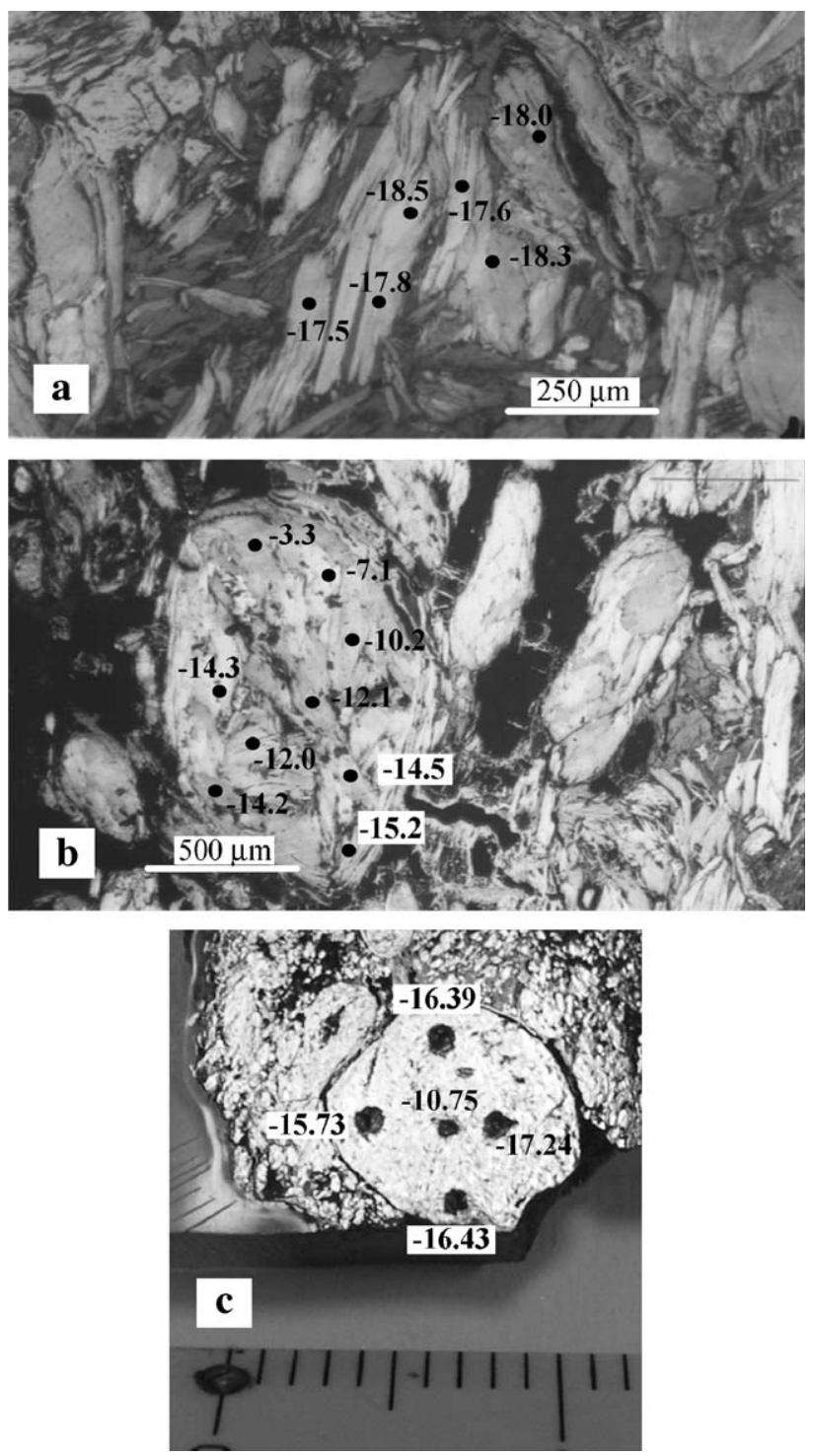

Fig. 6. a) $\delta^{13} \mathrm{C}$ values of flaky graphite crystals from Mina Marbella occurrence (SIMS data); b) $\delta^{13} \mathrm{C}$ values of nodule-like graphite aggregate from Mina Marbella occurrence (SIMS data); c) Hand sample of a $7 \mathrm{~mm}$ nodule-like graphite aggregate from Mina Marbella showing sampling areas for conventional mass spectrometry analysis with indication of corresponding $\delta^{13} \mathrm{C}$ values. 


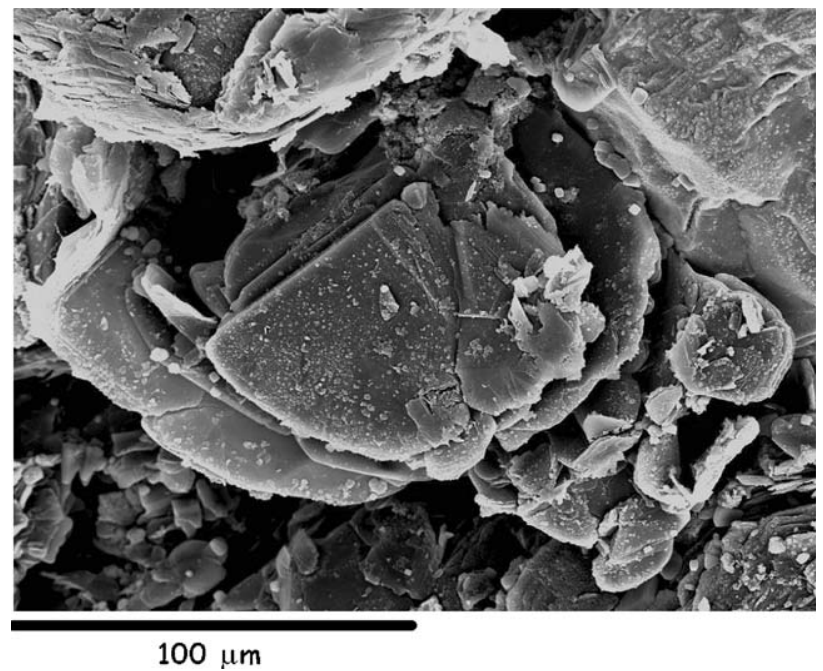

Fig. 7. SEM image of a nodule-like graphite aggregate from Mina Marbella showing a nucleus with cubic morphology surrounded by laminar graphite crystals. These nuclei have been interpreted as relicts of graphitised diamonds (see text).

from the organic matter contained in the subducted slab. Such an isotopic signature is very close to that of most of the studied $\mathrm{S}-\mathrm{G}$ occurrences. This hypothesis, however, would need to consider the possible effect of devolatilization going on during subduction (Kerrick and Connolly, 2001).

Alternatively, carbon can be added to magmas during assimilation processes either by fractional melting or total fusion of graphite-bearing metapelites. This mechanism has been invoked by Ripley et al. (2002) to explain the presence of graphite associated with magmatic $\mathrm{Ni}-\mathrm{Cu}-\mathrm{Co}$ sulfide mineralization. Carbon would be added in the form of $\mathrm{CO}_{2}$ and $\mathrm{CH}_{4}$ by reaction of graphite with $\mathrm{O}$ - and $\mathrm{H}$-bearing melt species. In the ultramafic rocks of Beni Bousera, Pearson et al. (1991b) proposed that carbon was incorporated into the melts due to the migmatization of surrounding gneisses during the emplacement of the peridotites into the crust. This process is supported by the occurrence of granitic dikes cropping out within the peridotites (Pereira et al., 2003). However, in some places these granitic dikes cut previously formed $\mathrm{Cr}-\mathrm{Ni}$ ores (Gervilla and Leblanc, 1990). Thus, migmatization and formation of granitic rocks clearly postdated the magmatic mineralization event. Therefore, field evidence does not support crustal contamination during emplacement of the peridotite rocks.

Another geologically likely possibility is that crustal carbon was recycled during subduction of the lithosphere into the mantle (Mattey, 1987; Zhu and Ogasawara, 2002; Ohta et al., 2003). Such a process has been argued to explain the presence of isotopically light graphite in graphite-bearing mantle eclogites (Schulze et al., 1997). At this point we must consider the presence of graphitized diamonds within some garnet pyroxenites both in the Beni Bousera and Ronda peridotites. These graphite-bearing garnet pyroxenites have been interpreted as the result of the HP-UHP transformation of the subducted oceanic crust and kerogen-rich sediments into the mantle (Davies et al., 1993; Pearson et al., 1991b, 1995; Pearson and Nixon, 1996). The isotopic signature of these graphitized diamonds in the Beni Bousera massif ranges from $-16.4 \%$ o to $-27.6 \%$, with a mode around $-21 \%$ (Pearson et al., 1991b). Carbon extracted from clinopyroxene in graphitebearing garnet pyroxenite from Beni Bousera yielded a $\delta{ }^{13} \mathrm{C}=-21.1 \%$. Such carbon is interpreted as lattice-held $\mathrm{CO}_{2}$ trapped during clinopyroxene growth in the mantle (Pearson et al., 1991b). This implies that the biogenic signature of carbon was preserved in the sediments subducted along with the oceanic crust that ultimately resulted in the formation of the different types of pyroxenite layers. It must be emphasized that some pyroxenite layers have even preserved the original major element geochemistry of the subducted crustal rocks (Morishita et al., 2003).

The isotopic range for graphitized diamonds from Beni Bousera pyroxenites also encompasses the $\delta^{13} \mathrm{C}$ values of graphite in the $\mathrm{Cr}-\mathrm{Ni}$ ores and in most of the $\mathrm{S}-\mathrm{G}$ ores (except those of nodule-like aggregates from Mina Marbella; Table 2). If such an original carbon isotope composition is considered, then the lighter $\delta{ }^{13} \mathrm{C}$ values found in graphite from the $\mathrm{Cr}-\mathrm{Ni}$ ores in the studied occurrences can be easily explained. Considering the stability fields of minerals in the observed assemblages, the maximum temperature of formation of $\mathrm{Cr}-\mathrm{Ni}$ ores has been estimated to be close to $1000{ }^{\circ} \mathrm{C}$ (Gervilla and Leblanc, 1990). At temperatures in the range from 1000 to $800{ }^{\circ} \mathrm{C}$ (the temperature estimated for re-equilibration of the mineral assemblage), the carbon isotope fractionation between $\mathrm{CO}_{2}$ and graphite is in the range from $3 \%$ to $5 \%$ at $1000{ }^{\circ} \mathrm{C}$ to about $5 \%$ to $7 \%$ at $800{ }^{\circ} \mathrm{C}$ (Bottinga, 1969; Chacko et al., 1991). Therefore, carbon isotope signatures of graphite in the $\mathrm{Cr}-\mathrm{Ni}$ ores as light as $-26.1 \%$ (the lightest found for this type of mineralization; Table 2) could be obtained from $\mathrm{CO}_{2}$ with $\delta^{13} \mathrm{C}$ close to $-21 \%$ to $-19 \%$ in the parent melt. The formation of lighter graphite in the $\mathrm{Cr}-\mathrm{Ni}$ ores would lead to a ${ }^{13} \mathrm{C}$-enriched residual $\mathrm{CO}_{2}$, which could explain the heavier $\delta{ }^{13} \mathrm{C}$ values of graphite in the $\mathrm{S}-\mathrm{G}$ ores with respect to both original $\mathrm{CO}_{2}$ (that found in the clinopyroxenes) and graphite in the $\mathrm{Cr}-\mathrm{Ni}$ ores (assuming a common origin for the $\mathrm{S}-\mathrm{G}$ and $\mathrm{Cr}-\mathrm{Ni}$ ores as discussed below). In addition, the differences in carbon isotope signatures among the occurrences in each massif could imply regional variations in the carbon sources from massif to massif. The small isotopic variation of flaky graphite within each individual $\mathrm{S}-\mathrm{G}$ occurrence (both in Beni Bousera and Ronda) indicates that graphite crystallized in a small temperature range.

A particular case is represented by the nodule-like aggregates in the $\mathrm{S}-\mathrm{G}$ ores from Mina Marbella. In this occurrence, the isotopic signature of the diamond pseudomorphs within the aggregates show heavier values $\left(\delta^{13} \mathrm{C}=-3.3 \%\right.$ ). The only isotopic value available for the graphitized diamonds in the Ronda peridotite $\left(\delta^{13} \mathrm{C}=+1 \%\right.$; Pearson et al., 1991b) is significantly heavier than those in the Beni Bousera peridotite. Such a heavy carbon isotope composition is again outside the typical mantle isotopic range. It is interpreted as a product of subducting sea floor carbonate into the mantle, possibly in the form of hydrothermal calcite veins in the oceanic crust (Pearson et al., 1995). Therefore, the heavy cores of the nodule-like aggregates in the $\mathrm{S}-\mathrm{G}$ ores from Mina Marbella 
might indicate derivation from a heavier carbon source (probably subducted carbonate). Thus, it may be concluded that two different carbon reservoirs were involved during the genesis of the $\mathrm{S}-\mathrm{G}$ deposits in the ultramafic massifs of Ronda: a light biogenic carbon and a heavier carbonate-derived carbon. Both types of carbon were incorporated into the mantle by subduction processes, resulting in the formation of diamonds at mantle conditions. Considering the volume of light graphite (derived from the biogenic source) and heavy graphite (formed from carbonate carbon) in the studied ores, biogenic carbon was by far more abundant. Locally, the isotopic exchange of light carbon in the melts with isotopically heavier graphitized diamonds would produce marked isotopic zoning. Such a process is evidenced from the progressively lighter carbon isotopic signature towards the outer zones of the nodule-like graphite aggregates in Mina Marbella. The replacement process of the pseudomorphs would obliterate the original preferred orientation of the graphite crystals (basal planes of graphite displayed parallel to the (111) planes of diamond; Slodkevich, 1983; Pearson et al., 1989). In fact, the cubic forms in the nodule-like aggregates in the $\mathrm{S}-\mathrm{G}$ ores are very small (edges about $50 \mu \mathrm{m}$ ) compared to the original size of the graphitized diamonds in the pyroxenites $(1-20 \mathrm{~mm})$.

\subsection{Mechanism of carbon concentration}

The second key point of the $S-G$ mineralization refers to the way in which carbon was concentrated. To explain this point we must consider the genetic model proposed for these magmatic deposits in the ultramafic rocks of Ronda and Beni Bousera.
During the Cenozoic evolution of the Alborán basin there was a thinning of the lithospheric mantle that promoted pervasive partial melting of the peridotites and $\mathrm{km}$-scale, asthenospheric-derived melt infiltration (Van der Wal and Bodinier, 1996; Garrido and Bodinier, 1999; Tubía et al., 2004). When upward migrating melts reacted with the host peridotites and pyroxenite layers they underwent fractional crystallization and segregated volatile-rich, residual smallvolume melts (Garrido and Bodinier, 1999). It must be highlighted that pyroxenites comprise about $5 \%$ in volume of the ultramafic massifs, and that graphite-bearing pyroxenites contain up to $15 \%$ graphite (Pearson et al., 1989; Davies et al., 1993). Therefore, a large amount of carbon would be available during the partial melting of the peridotites and pyroxenite layers by the asthenosphere-derived melts.

The residual, small-volume melts concentrated the volatile components (mainly $\mathrm{CO}_{2}$ and $\mathrm{H}_{2} \mathrm{O}$ ), as well as $\mathrm{S}$, As, and chalcophile elements. In this way, the parental melts of the $\mathrm{Cr}-$ $\mathrm{Ni}$ and $\mathrm{S}-\mathrm{G}$ ores were formed. The first melts that reached the recrystallization front proceeded from partial melting (and melt-rock reactions) of peridotites and pyroxenites rich in nickel arsenides and carbon (formerly diamonds and also $\mathrm{CO}_{2}$ contained in clinopyroxenes). Those melts were therefore the most effective to form arsenide- and sulfide-rich deposits. The earlier As saturation of these melts formed the $\mathrm{Cr}-\mathrm{Ni}$ ores which in turn involved the $\mathrm{S}$ saturation of the residual melt, resulting in the segregation of an immiscible sulfide melt that collected the most incompatible elements (Gervilla et al., 1996, 2002). Thus, the whole process could be regarded as an extreme fractional crystallization. It must be noted that, whatever the carbon source, a large initial carbon concentration

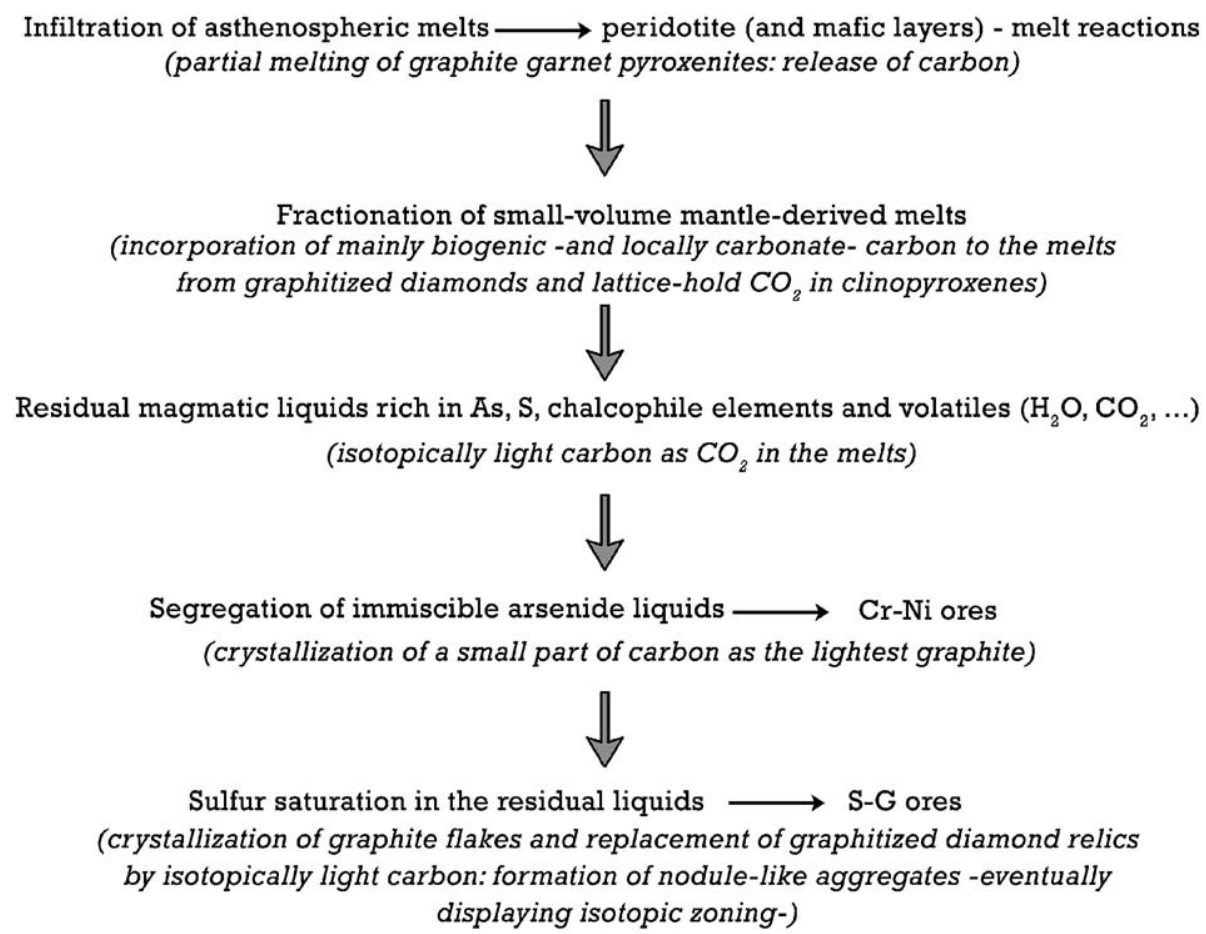

Fig. 8. Summary of the genesis and evolution of the magmatic mineralization processes in the peridotite rocks of Ronda and Beni Bousera, showing the stages of carbon evolution and concentration. 
is not essential, because due to the incompatible behaviour of carbon it would be concentrated in the residual melts. Only a very small fraction of the carbon content was incorporated into the arsenide-rich melts crystallizing in the $\mathrm{Cr}-\mathrm{Ni}$ ores as the lightest graphite $\left(\delta^{13} \mathrm{C}=-26.1 \%\right.$ to $-19.9 \%$ ). In this way, the parental melts of the $\mathrm{S}-\mathrm{G}$ ores concentrated most of the available carbon $\left({ }^{13} \mathrm{C}\right.$-enriched) and probably some refractory graphitized diamond relicts derived from replaced, nearby diamond-bearing pyroxenites. Locally, reaction of the light carbon in the melts with ${ }^{13} \mathrm{C}$-enriched graphitized diamonds (probably generated from a carbonate carbon source) would promote isotopic exchange producing the observed large isotopic zoning in the nodule-like aggregates from Mina Marbella. The mechanisms responsible for graphite crystallization from these sulfide-rich melts still remain unclear. Graphite is stable at shallow levels in the mantle at relatively low $\mathrm{fO}_{2}$ conditions (Blundy et al., 1991) like those prevailing during the formation of the $\mathrm{S}-\mathrm{G}$ ores. In addition, it is also known that sulfides catalyze the crystallization of graphite (see Luque et al., 1998, and references therein).

Finally, as the peridotite rose, it was progressively cooled and the partial melting and melt migration front (the recrystallization front) moved to deeper horizons within the mantle. The amount of melts that crossed the recrystallization front was progressively smaller and this is the reason why the largest $\mathrm{Cr}-\mathrm{Ni}$ and $\mathrm{S}-\mathrm{G}$ ores are found in the spinel tectonite domain. Carbon isotope data show that there is no systematic difference between graphite in occurrences associated with granular peridotite and spinel tectonite. Thus, the carbon isotopes do not reveal a particular signature for the granular peridotite "front," which implies that neither carbon sources nor graphite-forming mechanisms appear to be affected by, or controlled by, the front.

\section{Conclusions}

The graphite-sulfide deposits in the ultramafic rocks of southern Spain and Beni Bousera (Morocco) are an unusual type of magmatic mineralization. They represent volumetrically large carbon accumulations in mantle-derived rocks. These deposits were formed from residual melts that resulted from partial melting (and melt-rock reactions) of peridotites and pyroxenites by asthenospheric-derived melts. These residual melts concentrated volatile components (mainly $\mathrm{CO}_{2}$ and $\mathrm{H}_{2} \mathrm{O}$ ), as well as $\mathrm{S}, \mathrm{As}$, and chalcophile elements.

Carbon was incorporated into the melts from the melt-rock reactions of graphite (formerly diamonds) garnet pyroxenites with infiltrated asthenospheric melts. Graphite-rich garnet pyroxenites formed through the UHP transformation of the subducted oceanic crust along with kerogen-rich crustal material into the mantle. This explains the light (biogenic) signatures of graphite in most of the studied occurrences. The early $\mathrm{Cr}-\mathrm{Ni}$ ores consumed only a very small fraction of the available carbon that crystallized as the lightest graphite. The $\mathrm{S}-\mathrm{G}$ ores formed later and concentrated most of the carbon. These processes are outlined in the Fig. 8. Locally, reaction of the light carbon in the melts with relicts of ${ }^{13} \mathrm{C}$-enriched graphitized diamonds (probably generated from hydrothermal calcite veins in the subducting oceanic crust) reacted with the partial melts to form isotopically zoned nodule-like graphite aggregates as those found in Mina Marbella.

\section{Acknowledgements}

The paper has benefited from comments by J.F. Barrenechea on an earlier version. We also thank S. Dunn and M. SatishKumar for helpful reviews and Rosa Rojas for assistance during the thermal analyses. This work has been supported by Project PB98-0836 of the Spanish CICYT.

\section{References}

Arita, Y., Wada, H., 1990. Stable isotopic evidence for migration of metamorphic fluids along grain boundaries of marbles. Geochemical Journal 24, 173-186.

Ballhaus, C.G., Stumpfl, E.F., 1985. Occurrence and petrological significance of graphite in the Upper Critical Zone, western Bushveld Complex, South Africa. Earth and Planetary Science Letters 74, 58-68.

Barrenechea, J.F., Luque, F.J., Rodas, M., Pasteris, J.D., 1997. Vein-type graphite mineralization in the Jurassic volcanic rocks of the external zone of the Betic Cordillera (southern Spain). Canadian Mineralogist 35, $1379-1390$.

Blichert-Toft, J., Ablated, F., Kornprobst, J., 1999. Lou-Hf isotope systematics of garnet pyroxenites from Beni Bousera, Morocco. Implications for basalt origin. Science 283, 1303-1306.

Blundy, J.D., Brodholt, J.P., Wood, B.J., 1991. Carbon-fluid equilibria and the oxidation state of the upper mantle. Nature 349, 321-324.

Bottinga, Y., 1969. Carbon isotope fractionation between graphite, diamond and carbon dioxide. Earth and Planetary Science Letters 5, 301-307.

Cartigny, P., Harris, J.W., Javoy, M., 1998. Eclogitic diamond formation at Jwaneng: no room for a recycled component. Science 280, 1421-1424.

Chacko, T., Mayeda, T.K., Clayton, R.N., Goldsmith, J.R., 1991. Oxygen and carbon isotope fractionation between $\mathrm{CO}_{2}$ and calcite. Geochimica et Cosmochimica Acta 45, 411-419.

Davies, G.R., Nixon, P.H., Pearson, D.G., Obata, M., 1993. Tectonic implications of graphitized diamonds from the Ronda peridotite massif, southern Spain. Geology 21, 471-474.

Deines, P., 2002. The carbon isotope geochemistry of mantle xenoliths. EarthScience Reviews 58, 247-278.

Eggler, D.H., Holloway, J.R, Mysen, B.O., 1976. High $\mathrm{CO}_{2}$ solubilities in mantle magmas. Comment. Geology 4, 198-199.

Garrido, C.J., Bodinier, J.L., 1999. Diversity of mafic rocks in the Ronda peridotite: evidence for pervasive melt-rock reaction during heating of subcontinental lithosphere by upwelling asthenosphere. Journal of Petrology 40, 729-754.

Gervilla, F., Leblanc, M., 1990. Magmatic ores in high-temperature alpine-type lherzolite massifs (Ronda, Spain, and Beni Bousera, Morocco). Economic Geology 85, 112-132.

Gervilla, F., Leblanc, M., Torres-Ruiz, J., Fenoll Hach-Alí, P., 1996. Immiscibility between arsenide and sulfide melts: a mechanism for the concentration of noble metals. Canadian Mineralogist 34, 485-502.

Gervilla, F., Gutiérrez-Narbona, R., Fenoll, P., 2002. The origin of different types of magmatic mineralizations from small-volume melts in the lherzolite massifs of the Serranía de Ronda (Málaga, Spain). Boletín de la Sociedad Española de Mineralogía 25, 79-96.

Gurney, J.J., 1990. The diamondiferous roots of our wandering continent. South African Journal of Geology 93, 423-437.

Hollister, V.F., 1980. Origin of graphite in the Duluth Complex. Economic Geology 75, 764-766.

Kerrick, D.M., Connolly, J.A.D., 2001. Metamorphic devolatilization of subducted marine sediments and the transport of volatiles into the Earth's mantle. Nature 411, 293-296. 
Kirkley, M.B., Gurney, J.J., Otter, M.L., Hill, S.J., Daniels, L.R., 1991. The application of $\mathrm{C}$ isotope measurements to the identification of the sources of C in diamonds: a review. Applied Geochemistry 6, 477-494.

Kornprobst, J., Piboule, M., Roden, M., Tabit, A., 1990. Corundum-bearing garnet clinopyroxenites at Beni Bousera (Morocco): original plagioclaserich gabbros recrystallized at depth within the mantle? Journal of Petrology $31,717-745$.

Leech, M.L., Ernst, W.G., 1998. Graphite pseudomorphs after diamond? A carbon isotope and spectroscopic study of graphite cuboids from the Maksyutov Complex, south Ural Mountains, Russia. Geochimica et Cosmochimica Acta 62, 2143-2154.

Lenoir, X., Garrido, C., Bodinier, J.L., Dautria, J.M., Gervilla, F., 2001. The recrystallization front of the Ronda peridotite: thermal erosion and melting of the subcontinental lithospheric mantle beneath the Alborán basin. Journal of Petrology 42, 141-158.

Lowenstern, J.B., 2001. Carbon dioxide in magmas and implications for hydrothermal systems. Mineralium Deposita 36, 490-502.

Luque, F.J., Rodas, M., Galán, E., 1992. Graphite vein mineralization in the ultramafic rocks of southern Spain: mineralogy and genetic relationships. Mineralium Deposita 27, 226-233.

Luque, F.J., Barrenechea, J.F., Rodas, M., 1993. Graphite geothermometry in low and high temperature regimes: two case studies. Geological Magazine 130, 501-511.

Luque, F.J., Pasteris, J.D., Wopenka, B., Rodas, M., Barrenechea, J.F., 1998. Natural fluid-deposited graphite: mineralogical characteristics and mechanisms of formation. American Journal of Science 298, 471-498.

Maruoka, T., Kurat, G., Dobosi, G., Koeberl, C., 2004. Isotopic composition of carbon in diamonds and diamondites: record of mass fractionation in the upper mantle. Geochimica et Cosmochimica Acta 68, 1635-1644.

Mathez, E.A., 1987. Carbonaceous matter in mantle xenoliths: composition and relevance to the isotopes. Geochimica et Cosmochimica Acta 51, $2339-2347$.

Mattey, D.P., 1987. Carbon isotopes in the mantle. Terra Cognita 7, 31-37.

Mattey, D.P., 1991. Carbon dioxide solubility and carbon isotope fractionation in basaltic melt. Geochimica et Cosmochimica Acta 55, 3467-3473.

Milledge, H.J., Mendelssohn, M.J., Seal, M., Rouse, J.E., Swart, P.K., Pillinger, C.T., 1983. Carbon isotopic variation in spectral type II diamonds. Nature 303, 791-792.

Morishita, T., Arai, S., Gervilla, F., Green, D.H., 2003. Closed-system geochemical recycling of crustal materials in alpine-type peridotite. Geochimica et Cosmochimica Acta 67, 303-310.

Ohta, M., Mock, T., Ogasawara, Y., Rumble, D., 2003. Oxygen, carbon and strontium isotope geochemistry of diamond-bearing carbonate rocks from Kumdy-Kol, Kokchetav Massif, Kazakshtan. Lithos 70, 77-90.

Pawley, A.R., Holloway, J.R., McMillan, P.F., 1992. The effect of oxygen fugacity on the solubility of carbon-oxygen fluids in basaltic melt. Earth and Planetary Science Letters 110, 213-225.

Pearson, D.G., Nixon, P.H., 1996. Diamonds in young orogenic belts: graphitised diamonds from Beni Bousera, N. Morocco, a comparison with kimberlite-derived diamond occurrences and implications for diamond genesis and exploration. Africa Geoscience Reviews 3, 295-316.

Pearson, D.G., Nowell, G.M., 2004. Re-Os and Lu-Hf isotope constraints on the origin and age of pyroxenites from Beni Bousera peridotite massif: implications for mixed peridotite-pyroxenite mantle sources. Journal of Petrology 45, 439-455.

Pearson, D.G., Davies, G.R., Nixon, P.H., Milledge, H.J., 1989. Graphitized diamonds from a peridotite massif in Morocco and implications for anomalous diamond occurrences. Nature 338, 60-62.

Pearson, D.G., Davies, G.R., Nixon, P.H., Greenwood, P.B., Mattey, D.P., 1991a. Oxygen isotope evidence for the origin of pyroxenites in the Beni Bousera peridotite massif, N. Morocco: derivation from subducted oceanic lithosphere. Earth and Planetary Science Letters 102, 289-301.

Pearson, D.G., Davies, G.R., Nixon, P.H., Mattey, D.P., 1991b. A carbon isotope study of diamond facies pyroxenites and associated rocks from the Beni Bousera peridotite, North Morocco. Journal of Petrology, Special Lherzolites Issue, 175-189.
Pearson, D.G., Davies, G.R., Nixon, P.H., 1993. Geochemical constraints on the petrogenesis of diamond facies pyroxenites from the Beni Bousera peridotite massif, North Morocco. Journal of Petrology 34, 125-172.

Pearson, D.G., Boyd, F.R., Haggerty, S.E., Pasteris, J.D., Field, S.W., Nixon, P.H., Pokhilenko, N.P., 1994. The characterisation and origin of graphite in cratonic lithospheric mantle: a petrological carbon isotope and Raman spectroscopic study. Contributions to Mineralogy and Petrology 115, 449-466.

Pearson, D.G., Davies, G.R., Nixon, P.H., 1995. Orogenic ultramafic rocks of UHP (diamond facies) origin. In: Coleman, R.G., Wang, X. (Eds.), Ultrahigh Pressure Metamorphism, pp. 456-510.

Pereira, M.D., Shaw, D.M., Acosta, A., 2003. Mobile trace elements and fluiddominated processes in the Ronda peridotite, southern Spain. Canadian Mineralogist 41, 617-625.

Pineau, F., Javoy, M., Kornprobst, J., 1987. Primary igneous graphite in ultramafic xenoliths: II. Isotopic composition of the carbonaceous phases present in xenoliths and host lava at Tissemt (Algerian Sahara). Journal of Petrology 28, 313-322.

Ripley, E.M., Taib, N.I., 1989. Carbon isotopic studies of metasedimentary and igneous rocks at the Babbitt $\mathrm{Cu}-\mathrm{Ni}$ deposit, Duluth Complex, Minnesota, U.S.A.. Chemical Geology (Isotope Geoscience Section) 73, 319-342.

Ripley, E.M., Li, C., Shin, D., 2002. Paragneiss assimilation in the genesis of magmatic $\mathrm{Ni}-\mathrm{Cu}-\mathrm{Co}$ sulfide mineralization at Voisey's Bay, Labrador: $\delta^{34} \mathrm{~S}, \delta^{13} \mathrm{C}$, and $\mathrm{Se} / \mathrm{S}$ evidence. Economic Geology 97, 1307-1318.

Sánchez-Gómez, M., Balanyá, J.C., García-Dueñas, V., Azañón, J.M., 2002. Intracrustal tectonic evolution of large lithosphere mantle slabs in the western end of the Mediterranean orogen (Gibraltar arc). Journal of the Virtual Explorer 8, 23-34.

Sánchez-Rodríguez, L., Gebauer, D., 2000. Mesozoic formation of pyroxenites and gabbros in the Ronda area (southern Spain), followed by Early Miocene subduction metamorphism and emplacement into the middle crust: $\mathrm{U}-\mathrm{Pb}$ sensitive high-resolution ion microprobe dating of zircon. Tectonophysics $316,19-44$.

Satish-Kumar, M., Wada, H., Santosh, M., 2002. Constraints on the application of carbon isotope thermometry in high- to ultrahigh-temperature metamorphic terranes. Journal of Metamorphic Geology 20, 335-350.

Schulze, D.J., Valley, J.W., Viljoen, K.S., Stiefenhofer, J., Spicuzza, M., 1997. Carbon isotope composition of graphite in mantle eclogites. Journal of Geology 105, 379-386.

Shengelia, D.M., Akhvlediani, R.A., Ketskhoveli, D.N., 1979. The graphite geothermometer. Doklady Academii Nauk SSSR 235, 132-134.

Slodkevich, V.V., 1983. Graphite paramorphs after diamond. International Geology Reviews 25, 497-514.

Strens, R.G.J., 1965. The graphite deposit of Seathwaite in Borrowdale, Cumberland. Geological Magazine 102, 393-406.

Tagiri, M., 1981. A measurement of the graphitizing-degree by the X-ray powder diffractometer. Journal of the Japanese Association of Mineralogists, Petrologists and Economic Geologists 76, 345-352.

Tappert, R., Stachel, T., Harris, J.W., Muehlenbachs, K., Ludwig, T., Brey, G.P., 2005. Subducting oceanic crust: the source of deep diamonds. Geology 33 , $565-568$.

Tubía, J.M., Cuevas, J., Esteban, J.J., 2004. Tectonic evidence in the Ronda peridotites, Spain, for mantle diapirism related to delamination. Geology $32,941-944$.

Van der Wal, D., Bodinier, J.L., 1996. Origin of the recrystallization front in the Ronda peridotite by $\mathrm{km}$-scale pervasive porous melt flow. Contributions to Mineralogy and Petrology 122, 387-405.

Wada, H., 1988. Microscale isotopic zoning in calcite and graphite crystals in marble. Nature 331, 61-63.

Wyllie, P.J., Huang, W.L., 1976. High $\mathrm{CO}_{2}$ solubilities in mantle magmas. Geology 4, 21-24.

Wopenka, B., Pasteris, J.D., 1993. Structural characterization of kerogens to granulite-facies graphite: applicability of Raman microprobe spectroscopy. American Mineralogist 78, 533-557.

Zhu, Y., Ogasawara, Y., 2002. Carbon recycled into deep earth: evidence from dolomite dissociation in subduction-zone rocks. Geology 30, 947-950. 